UDC 532.5, 532.6

S. V. Pasechnik, D. V. Shmeliova ${ }^{I}$, A. V. Dubtsov ${ }^{I}$, S. V. Trifonov ${ }^{I}$, V. G. Chigrinov ${ }^{2}$

\title{
ELECTRICALLY INDUCED SHEAR FLOWS OF LIQUID CRYSTALS CONFINED TO POROUS POLYMER FILMS FOR THz APPLICATION
}

${ }^{1}$ Problem Laboratory of Molecular Acoustics, Moscow Technological University, 20 Stromynka St., Moscow, 107996, Russia. E-mail: s-p-a-s-m@mail.ru

${ }^{2}$ Hong Kong University of Science and Technology,

Clear Water Bay, Kowloon, Hong Kong. E-mail: eechigr@ust.hk

In this paper we consider new possibilities to control the THz irradiation via usage of the previously studied [1] electro-kinetic phenomena in the porous polymer (PET) film filled with a nematic liquid crystal $(N L C)$. It is shown that a sample of the porous film may play the role of electro-hydrodynamic (EHD) pump, which induces a shear Poiseuille flow of NLC through the sandwich-like cell connected with the pump. The shear flow results in changing of the initial orientation of $L C$, which can be used to control the THz irradiation passing through the sandwich-like cell.

Key words: liquid crystals, electro-hydrodynamic (EHD) pump, electro-kinetic phenomena.

DOI: 10.18083/LCAppl.2018.1.79

\section{С. В. Пасечник', Д. В. Шмелева ${ }^{1}$, А. В. Дубцов ${ }^{1}$, С. В. Трифонов ${ }^{1}$ В. Г. Чигринов ${ }^{2}$}

\section{ЭЛЕКТРИЧЕСКИ ИНДУЦИРОВАННЫЕ СДВИГОВЫЕ ПОТОКИ ЖИДКИХ КРИСТАЛЛОВ, ОГРАНИЧЕННЫЕ ПОРИСТЫМИ ПОЛИМЕРНЫМИ ПЛЕНКАМИ ДЛЯ ТЕРАГЕРЦОВЫХ ПРИМЕНЕНИЙ}

\footnotetext{
${ }^{1}$ Московский технологический университет, Проблемная лаборатория молекулярной акустики, ул. Стромынка, 20, 107996 Москва, Россия. E-mail: s-p-a-s-m@ mail.ru ${ }^{2}$ Гонконгский университет науки и технологии, Залив Чистой Воды, Коулун, Гонконг. E-mail: eechigr@ust.hk
}

В данной работе рассматриваются новые возможности контроля терагерцового излучения с использованием ранее изученных [1] электрокинетических явлений в пленке пористого полимера (ПЭТ), заполненной нематическим жидким кристаллом (НЖК). Показано, что образеи пористой пленки может играть роль электрогидродинамического (ЭГД) насоса, который индуцирует сдвиговое течение Пуазейля НЖК через «сэндвич»-ячейку, связанную с насосом. Сдвиговый поток приводит к изменению начальной ориентачии ЖК, что может применяться для контроля ТГи излучения, проходящего через «сэндвич»подобную ячейку.

Ключевые слова: жидкие кристалль, электро-гидродинамический насос, электрокинетические явления.

(C) Pasechnik S. V., Shmeleva D. V., Dubtsov A. V., Trifonov S. V., Chigrinov V. G., 2018 


\section{Introduction}

Development of $\mathrm{THz}$ technique for the last decades resulted in arising of a number of new applications like non-destructive distant control of materials, THz vision and high speed internet [2-5]. It demands elaboration of tunable quasi-optic components (modulators, polarization controllers, filters etc). Usage of liquid crystals (LC) is very attractive for this aim and different $\mathrm{LC}$ based $\mathrm{THz}$ devices were already proposed [6]. It demands to solve the specific problems, like quality of surface induced orientation and slow operating times, arising due to a relatively thick LC layers needed to manipulate the $\mathrm{THz}$ irradiation. Moreover, the electric control of an orientational structure and optical properties of LC, widely used for visible and near red irradiation, is restricted by high losses of $\mathrm{THz}$ waves in thin conductive ITO layers of standard LC cells. Recently we proposed [7] shear flows as an alternative tool for a control of LC structure, which makes it possible to overcome some restrictions, mentioned above.

The connection between translation motion and a director field $\boldsymbol{n}(\boldsymbol{r}, t)$ in shear flows of NLC is responsible for a number of specific phenomena. Some of them, like various instabilities induced by electric fields in thin layers of nematic liquid crystals or back flow effects arising at turning off electric fields are of a great practical importance in a display industry [8]. In this paper, we will focus on shear flows of LC arising at application of DC electric field to the porous PET films filled with LC. The experimental investigations of such flows [1] make it possible to predict technical parameters of terafluidic LC devices of different types.

\section{Experimental}

In general, electro-kinetic phenomena (EKP) arise when DC or low frequency electric field is applied to the channels of different shapes and sizes filled with polar liquids [9]. It originates due to absorption of polar molecules by the internal surface of a capillary which results in an appearance of the double electric layer with thickness $h_{0}$ (of order some nanometers for typical water solutions) and near surface diffusion layer of characteristic thickness $l_{D}$ (Debye length), expressed as [9]:

$$
l_{D}=k^{-1}=\left[\frac{\left(\varepsilon_{0} \varepsilon k_{B} T\right)}{2 e^{2} z^{2} n}\right]^{\frac{1}{2}},
$$

where $\varepsilon_{0}$ - permittivity of vacuum, $\varepsilon$ - dielectric permittivity, $k_{B}$ - Boltzmann constant, $T-$ absolute temperature, $e$ - elementary charge, $z$-ion valence, $n_{\infty}-$ bulk concentration of the ions. The ions in a diffuse layer begin motion after application of static or low frequency electric field $E_{z}$. It results in arising of overall steady (or oscillating) flow sensitive to the electric field direction with a velocity profile, dependent on the parameter $\mu=k R$ (for a channel of a circular cross section with a radia $R$ ). In particular, for $\mu<<1$ a velocity profile is close to the parabolic one, typical for the Poiseuille flow, while for $\mu \gg 1$ a specific "plug" profile takes place. It is characterized by a constant value of the linear velocity $v_{0}$ everywhere, except for a thin near surface layer of thickness $l_{s} \approx l_{D}$ with a high value of the velocity gradient. $\partial \mathrm{v} / \partial \mathrm{r} \approx v_{0} / l_{D}$. The corresponding expressions for volumetric flow rate through the capillary $Q_{i}$ as a function of the axial component $E_{z}$ of the electric field strength reads as [9]:

$$
Q_{i}=-\left(\varepsilon_{0} \varepsilon \xi\right)\left[\frac{\pi R^{2}}{\eta}\right] E_{z}, k R \cong 1,
$$

where $\eta$ - the shear viscosity of a liquid, $\zeta$ - so called zeta potential which is typically of order $10 \ldots 100 \mathrm{mV}$. Previously [1] we performed experiments with electroosmothic flows of liquid crystal 4-cyano-4'pentylbiphenyl (5CB) through the porous polymer polyethylene terephthalate (PET) films of thickness $h=23 \mu \mathrm{m}$, characterized by cylindrical open-end and randomly allocated pores, oriented normally to the film's surface. It turned out, that the predicted by equation (2) linear dependence $Q_{i}(U)$, in the range of the applied voltage $U=0 \ldots 30 \mathrm{~V}$ was valid not only for an isotropic phase but for a nematic phase too (Fig. 1).

It means that such composite material can be used for elaboration of a linear EHD pump, controlled by low voltage. The overall volumetric rate $Q$ of the pump is proportional to the total number $N$ of pores and can be expressed as:

$$
Q=Q_{i} N=Q_{i} N_{0} S,
$$

where $N_{0}$ - pore density, $S$ - surface area of the sample. Equations (2) and (3) can be used for calculation of the dependence $Q\left(E_{z}\right)$, which defines the efficiency of the pump. The values of material parameters needed for such calculations were estimated from the experimental data [1] as $\zeta=-12 \mathrm{mV}$, $\eta=0.032 \mathrm{~Pa} \cdot \mathrm{s}$ and $\varepsilon=7$ (for a nematic phase of 5CB). The values of $Q$, calculated for the sample $\left(S=1 \mathrm{~cm}^{2}\right)$ of a porous film with the pore density $N_{0}=10^{8} \mathrm{~cm}^{-2}$ are presented in Table. 


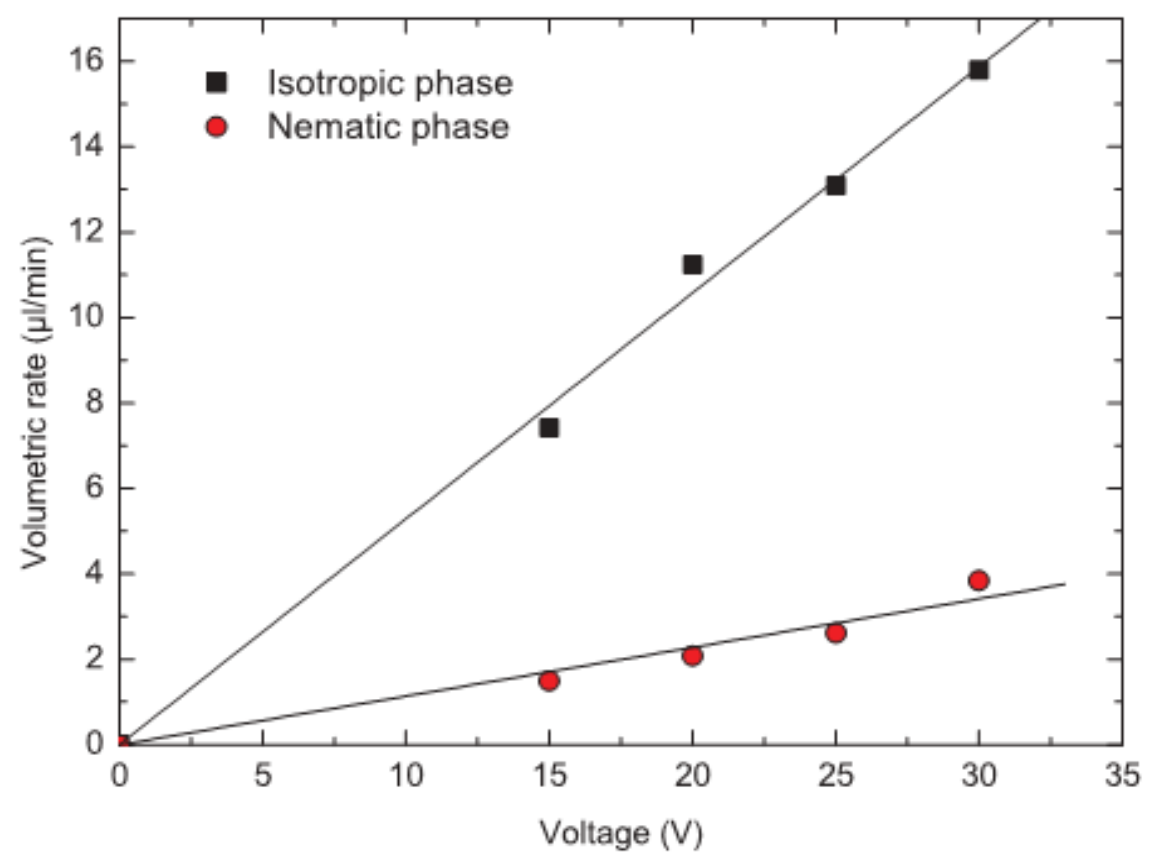

Fig. 1. Volumetric flow rate $Q$ for the sample of porous film with $R=150 \mathrm{~nm}$ as a function of applied voltage $U$ in isotropic $\left(T=60^{\circ} \mathrm{C}\right)$ and nematic $\left(T=25^{\circ} \mathrm{C}\right)$ phases of $5 \mathrm{CB}[1]$

\section{Results and discussion}

One of the ways to use LC EHD pump to control the THz irradiation is to provide circulation of LC through a standard sandwich-like cell (or another external hydrodynamic unit) connected with the pump (Fig. 2). In the case when the hydrodynamic resistance $Z_{e}$ of the external unit is essentially lower than the internal hydrodynamic resistance $Z_{i}$ of the pump the values of the flow rate $Q$, presented in Table are the same for the internal and external units of a hydrodynamic circuit. In our case, the values $Z_{e}$ and $Z_{i}$ are defined as:

$$
Z_{e}=\frac{12 L}{A d^{3}} \eta ; \quad Z_{i}=\frac{8 h}{\pi R^{4}} \eta,
$$

where $L, A$ and $d$ are, correspondently a length, a width and a gap of the plane capillary formed inside a sandwich-like cell. For the used above values of the EHD pump's parameters and with dimensions of a plane cell $A=L=1 \mathrm{~cm}, d=100 \mu \mathrm{m}$ the ratio $Z_{i} / Z_{e}$ is about 150 and the approximation of a constant value of $Q$ is valid. The pressure gradient $G=\Delta P / \Delta x$, arising in the plane cell due to viscous losses can be found from well-known expression:

$$
Q=\frac{G}{Z_{e}}
$$

The action of the flow, pumped through the plane cell on the orientation and optical properties of LC drastically depends on the initial orientation, stabilized by surfaces, and the experimental geometry. In particular, the initial homeotropic orientation with LC director normal to the plane substrates shows the maximal sensitivity to the action of the steady Poiseuille flow, realized in this hydrodynamic schema. In the linear regime the flow induced director distortions are confined by a flow plane and can be described by a polar angle $\theta(z)$, which can be expressed as [8]:

$$
\theta(z)=-\frac{a_{2}}{6 K_{22} \eta_{1}} \cdot z\left(z^{2}-\frac{d^{2}}{4}\right) \cdot G,
$$

where $K_{33}$ and $\eta_{1}$ are the Frank's elastic module and the Miesowicz viscosity coefficient corresponding to the initial configuration. The phase delay $\delta$ between the extraordinary (refraction coefficient $n_{e}$ ) and ordinary $\left(n_{o}\right)$ rays, propagating through LC layer, and induced by the orientational distortions can be defined as: 


$$
\begin{aligned}
& \delta \cong \frac{2 \pi d}{\lambda} \cdot \frac{n_{0}\left(n_{e}^{2}-n_{o}^{2}\right)}{2 n_{e}^{2}} \cdot\left\langle\theta^{2}\right\rangle= \\
& =\frac{1}{15120} \cdot \frac{\pi d}{\lambda} \cdot \frac{n_{o}\left(n_{e}^{2}-n_{o}^{2}\right)}{2 n_{e}^{2}} \cdot\left(\frac{\alpha_{2} G d^{3}}{K_{33} \eta_{1}}\right)^{2},
\end{aligned}
$$

where $\lambda$ - a wave length, $\alpha_{2}$ - the Leslie coefficient. It is worthwhile to notice, that equations (6) and (7) are valid only for a linear regime, when the maximal value $\theta_{m}$ of the angle $\theta$ :

$$
\theta_{m}=-\frac{\alpha_{2}}{18 \sqrt{3} K_{33} \eta_{1}} \cdot d^{3} \cdot G
$$

is essentially smaller, than $\pi$.

Contrary to the case of visible light, $\mathrm{THz}$ waves are characterized by essentially larger values of a wavelength $(30 \mu \mathrm{m}<\lambda<300 \mu \mathrm{m}$ for frequency range $f=10 \ldots 1 \mathrm{THz}$ ). It demands thicker layers (of order $1 \mathrm{~mm}$ ) to provide the value of $\delta$ close to $\pi$ needed for an effective modulation of the electromagnetic wave's intensity $I$, defined as:

$$
I=I_{0} \sin ^{2}\left(\frac{\delta}{2}\right),
$$

where $I_{0}$ - the input wave intensity. At the same time, surfaces stabilize the initial structure of liquid crystals only for relatively thin layers $(d<200 \mu \mathrm{m})$. So, multilayer structures are often used in this case [10]. It can also be simply realized in terafluidic LC modulator described above, due to usage a number $m$ of plane channels, connected in a parallel schema as an external unit. Obviously, it results in corresponding decreasing of the volumetric flow rate $Q m$ for each channel $\left(Q_{1}=Q / m\right)$ with simultaneous increasing of the phase delay $\left(\delta=\delta_{1} \mathrm{~m}\right)$ at the propagating of the wave through the multilayered structure. The results of calculations of the main parameters mentioned above for a wavelength $\lambda=60 \mu \mathrm{m}(f=5 \mathrm{THz})$ are presented in Table.

The calculations were made using material parameters of $5 \mathrm{CB}$ [11]: $K_{33}=8.2 \cdot 10^{-12} \mathrm{~N}$, and $\eta_{1}=0.1052 \mathrm{~Pa} \cdot \mathrm{s}, \alpha_{2}=-0.0812 \mathrm{~Pa} \cdot \mathrm{s}$. The values $n_{e}=1.715, n_{0}=1.534$ [12] correspond to the visible light. In spite of some wavelength dependence of the refractive indexes, the optical anisotropy $\Delta n=n_{e}-n_{0}$ which determines the phase delay is not changed essentially at decreasing of frequency to $1 \mathrm{THz}$ [6].

The data, shown in Table, demonstrate the possibility of elaboration of effective LC modulator of $\mathrm{THz}$ irradiation tuned by electroosmotic flow at relatively low (about $50 \mathrm{~V}$ ) operating voltages. The usage of multilayered external unit provides high efficacy of modulation for a linear regime of a director motion. This regime can be broken at high enough values of the pressure gradient $(>1000 \mathrm{~Pa} / \mathrm{m}$ for $d=100 \mu \mathrm{m}$ as it was estimated, for a $\mathrm{N}-(4-$ methoxybenzylidene)-4-butylaniline [8]). It results in an escape of a director from the flow plane. The further increasing of $G$ may induce the long living (up to some hours) instabilities and break the operation of the terafluidic LC modulator.

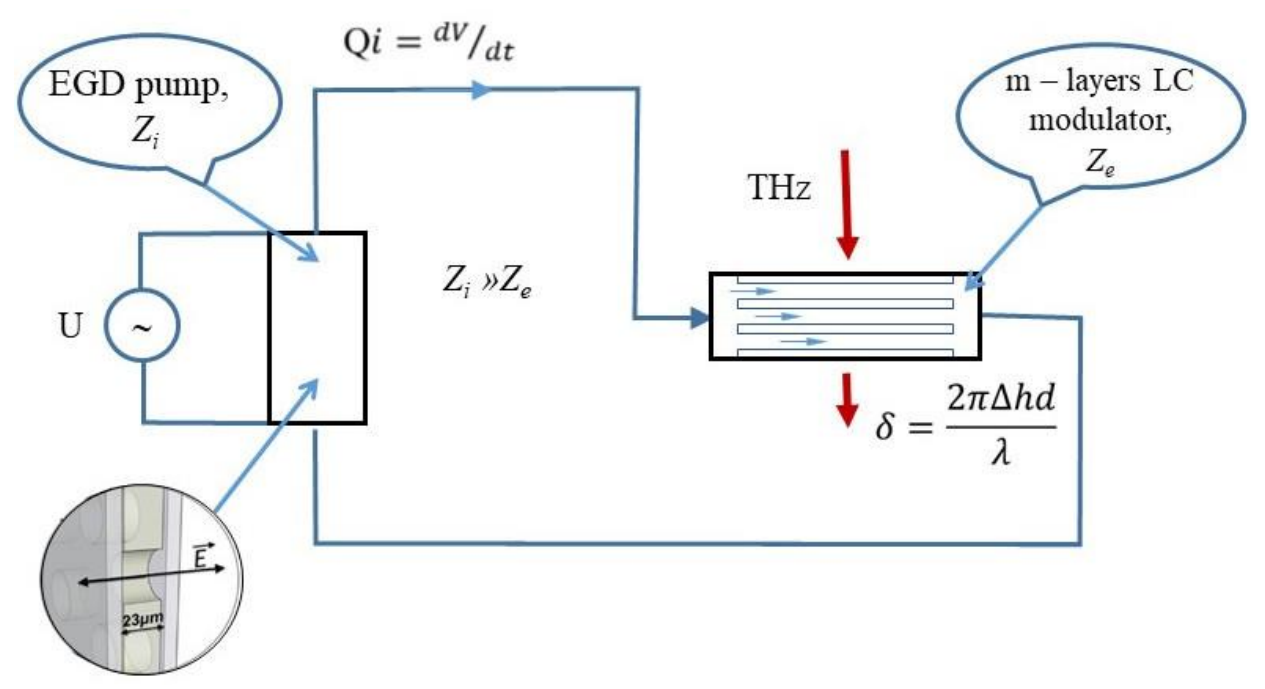

Fig. 2. Terafluidic LC modulator: hydrodynamic schema 
Table. Technical parameters of the terafluidic modulator

\begin{tabular}{|l|l|l|l|l|l|}
\hline$E_{z}, \mathrm{~V} / \mu \mathrm{m}$ & $Q, 10^{-12} \mathrm{~m}^{3} / \mathrm{s}$ & $G, \mathrm{~Pa} / \mathrm{m}$ for $\mathrm{m}=1 / 10$ & $\theta_{m}$, rad for $\mathrm{m}=1 / 10$ & $\delta / \pi$ for $\mathrm{m}=10$ & $I / I_{0} x 100 \%$ \\
\hline 0.01 & 0.233 & $89 / 8.9$ & $0.028 / 0.0028$ & 0.0112 & 0.0306 \\
\hline 0.1 & 2.33 & $890 / 89$ & $0.28 / 0.028$ & 0.112 & 3.06 \\
\hline 1.0 & 23.3 & $8900 / 890$ & $>(\pi / 2) / 0.28$ & 1.12 & $\approx 100$ \\
\hline
\end{tabular}

\section{Conclusion}

The existing information about electroosmotic flows in porous PET films were used to propose a new terafluidic LC modulator, based on integration of the electroosmotic unit, playing the role of LC EHD pump, and external unit, which can include one standard LC cell or multilayer structure. The detailed calculations were made for a linear regime of flow of the initially homeotropic layer (or layers) of a liquid crystal (5CB). It is shown that the multilayer structure provides operation of the terafluidic LC modulator at moderate voltages. The main advantage of such decision is the absence of electrodes in the region of $\mathrm{THz}$ wave. Further optimization of the technical characteristics can be achieved due to theoretical calculations and experimental investigations.

Acknowledgements: This work was supported by Ministry of Education and Science of Russian Federation, identification number - RFMEFI58316X0058.

\section{References}

1. Pasechnik S.V., Chopik A.P., Shmeliova D.V., Drovnikov E.M., Semerenko D.A., Dubtsov A.V., Zhang W. and Chigrinov V.G. Electro-kinetic phenomena in porous PET films filled with liquid crystals. Liquid Crystals, 2015, 42 (11), 1537-1542. DOI: $10.1080 / 02678292.2015 .1050853$.

2. Tonouch M. Cutting-edge terahertz technology. Nat. Photonics, 2007, 1, 97-105.

DOI: $10.1038 /$ nphoton.2007.3

3. Mittleman D. Terahertz Imaging. Sensing with terahertz radiation. Springer-Verlag Berlin Heidelberg, 2003, 117-153 DOI: 10.1007/978-3-540-45601-8.

4. Siegel P.H. Terahertz Technology. IEEE Transactions on Microwave Theory Technology, 2002, 50 (3), 910928. DOI: $10.1109 / 22.989974$.
5. Wietzke S., Jansen C., Jordens C., Krumbholz N., Vieweg N., Scheller M., Shakfa M.K., Romeike D., Hochrein T., Mikulics M., Koch M. Industrial applications of $\mathrm{THz}$ systems. Proceedings of SPIE: International Symposium on Photoelectronic Detection and Imaging, 2009, 7385, 738506-1-738506-13.

DOI: $10.1117 / 12.840991$.

6. Ci-Ling Pan, Ru-Pin Pan. Recent Progress in Liquid Crystal THz Optics. Proc. SPIE: XI Conf. on Liquid Crystal Materials, Devices, and Applications, 2006, 6135, 61350D-1-61350D-13.

DOI: $10.1117 / 12.644527$.

7. Pasechnik S.V., Shmeliova D.V. Terafluidic devices: Perspectives and Problems. IEEE 40th International Conference on Infrared, Millimeter and Terahertz Waves (IRMMW-THz2015). Hong Kong, China, 2015. P. 7327669.

DOI: $10.1109 /$ IRMMW-THz.2015.7327669.

8. Pasechnik S.V., Chigrinov V.G., Shmeliova D.V. Liquid crystals: viscous and elastic properties in theory and applications. Wiley-VCH Verlag $\mathrm{GmbH} \& \mathrm{Co}$. KGaA, Weinheim, 2009, 424 p.

DOI: $10.1002 / 9783527627660$.

9. Masliyah J.H., Bhattacharjee S. Electrokinetic and colloid transport phenomena. Hoboken: John Wiley and Sons, Inc., 2006, 736 p. DOI: 10.1002/0471799742.

10. Wilk R., Vieweg N., Kopschinski O., Koch M. Liquid crystal based electrically switchable Bragg structure for THz waves. Optics Express, 2009, 17 (9), 7377-7382. DOI: $10.1364 /$ OE.17.007377.

11. Stewart I.W. The Static and Dynamic Continuum Theory of Liquid Crystals: A mathematical introduction. London : Taylor \& Francis, 2004, 351 p.

12. Dunmur D. Physical Properties of Liquid Crystals: Nematics. London : INSPEC, 2001, 671 p. 